\title{
Assessment of State and Prospects for Development of Regional Agricultural Sector and Rural Areas
}

\section{Sergej Terentyev ${ }^{1}$, Alexej Kuchumov¹, Svetlana Sapozhnikova ${ }^{2}$, Valentina Kuptsova ${ }^{3}$, and Svetlana Chudakova ${ }^{3}$}

${ }^{1}$ Smolensk State Agricultural Academy, Smolensk, Russia ${ }^{2}$ Smolensk State University, Smolensk, Russia

${ }^{3}$ Smolensk branch of Russian University of Cooperation, Smolensk, Russia

Corresponding Author:

Sergej Terentyev

sgsha.nauka@mail.ru

Received: 25 October 2019

Accepted: 15 November 2019

Published: 25 November 2019

Publishing services provided by

Knowledge E

(c) Sergej Terentyev et al. This article is distributed under the terms of the Creative Commons

Attribution License, which

permits unrestricted use and

redistribution provided that the

original author and source are credited.

Selection and Peer-review under the responsibility of the AgroSMART 2019 Conference Committee.

\section{Abstract}

In conditions of market reforming in all development directions in Smolensk region, there are changes concerning the conditions, rules and principles of branches functioning in social and economic development of the region and its government. The main focus is on the development of only two industries working for export -- electricity production and mining industry. The region is located in Non-Black Earth Region and requires investment for the development of its agricultural sector. Therefore, it was decided to eliminate the sphere of agricultural sector, which in pre-perestroika period provided the domestic demand of the country population in pre-perestroika period. Agricultural sector also provided Far East and Polar regions. However, nowadays agricultural production is aimed only at meeting domestic regional demand. Even after the reforms, agricultural sector and its basic part farming continues to be a small island of real business working for domestic demand. It is a backbone component for the economy of Smolensk region, a source of labor market and force application of region rural population. It ensures its food and economic security and has a high potential for rural development. However, at present its position is in a state of crisis, which is associated with low procurement prices for perishable products, the elimination of a processing system and purchase of agricultural raw materials, seed stock, breeding farm, lack of own production of feed additives and animal feed; care of qualified personnel and specialists from the industry and deterioration of the social base (elimination of schools, settlements, hospitals and medical assistants, culture establishments). At the same time, the tasks are set to ensure food security in the context of sanctions, which leads to a noticeable revival of the industry. There are new concepts in industry regulation at the regional level, transformations in management methodology and interaction mechanism for all levels from modernization to processing of end products in accordance with the requirements of the country's development.

Keywords: region, subsidies, management system, development concepts

\section{G OPEN ACCESS}




\section{Introduction}

Smolensk region is located in the west of the country, and it has borders with Pskov, Tver, Moscow, Kaluga and Bryansk regions and the Republic of Belarus. It is a part of the Central Federal District, and a part of the Non-Black Earth Zone of the Russian Federation. Originally, agriculture was popular on the territory of the region where rural population prevailed as the main driver of development, providing people with high-quality food. However, the measures taken to reform the economy led to the inefficiency of the industry as supplying products to processing enterprises showed profit. Enterprises did not receive payment, did not have the funds to purchase current assets and pay wages. It led to the bankruptcy of many of them. Massive destruction of livestock began including breeding, agricultural areas were no longer processed. People left their homes, many settlements disappeared. There was a shift in population towards citizens. At the same time, local industrial enterprises in the cities of the region could not stand the competition and also went bankrupt. Hence, by 2007 , for the first time, the population of the region was less than 1 million, and is also actively decreasing. At the same time, the increase in external threats, primarily in terms of food security in the context of sanctions, is beginning to influence the position of restoring the pre-reform position of the agricultural sector. However, the measures taken are not sufficiently financed, fixed assets that are financed even by the state are not updated only through the banking system, creating additional obstacles to the development of agricultural business. Agricultural producers have tax privileges and preferences. There is a need to create an effective mechanism to function the agricultural sector and the interaction of both regional authorities and producers of agricultural products and equipment and process agricultural raw materials.

The question on possible development prospects and the need to support agricultural sector of Black Earth region are dealt with by many of the most prominent scientists of the country $[1,2,6,7]$.

At the same time, such areas as the organization of a new mechanism for the functioning of agricultural sector in the conditions of Non-Black Earth Region are not covered by creating one or two large state-owned specialized enterprises in each municipality for 200 to 500 workplaces that directly work with regional authorities to create modern material technical base, qualified personnel and organization of reliable marketing and processing of products. Such companies as previously machine tractor stations can help small agricultural enterprises with personnel and equipment. This will 
give a new life to the countryside, work places and provide a new impetus to the region development.

\section{Problem Statement}

The main problem in regional agricultural sector is the lack of funding, jobs, labor forces, equipment and technical base were destroyed and not restored. There are not enough current assets, state breeding farms were eliminated, ensuring the development of acclimatized varieties and livestock breeds, flax seed stations, etc. Thus, in creating effective agro-complexes in the region, it is necessary to organize a stable state infrastructure and create a working mechanism for the interaction of power, financial structures, agricultural business and society to create effective agricultural sector in the region.

\section{Research Questions}

Management system plays a special role in ensuring food security when there is the increasing competition from other countries in WTO system and agricultural holdings of Black Earth Zone of the Russian Federation. It includes a falling demand for agricultural products produced by local farmers due to its high cost, low infrastructure and high demands from retail side, restrictions on budget financing of the territory of high climatic risks, liquidation of a reliable system of state aid, procurement and lack of specialized enterprises that process agricultural raw materials. Moreover, the state proposes to solve these problems on their own or by organization of agricultural cooperatives.

Before perestroika period, agricultural sector was actively developing. The number of rural population was growing, and the area of agricultural land and the number of cattle were increasing.

In 1980, the area of agricultural crops amounted to more than 1.544 million hectares, including 592.2 thousand hectares of grain, 102 thousand hectares of flax; more than 800 thousand heads of cattle, including 121.7 thousand heads of cows. Currently, almost all indicators of the industry have fallen. Thus, the number of heads of cattle at the beginning of 2018 was 78.2 thousand hectares, including 35.1 cows, 282.2 pigs, and 2.8 thousand sheep and goats. The area of grain and leguminous in 2018 was 93.7 thousand hectares, 13.7 thousand hectares of flax. The total area of agricultural land in 2008 was 1697.7 thousand hectares with a total land area of 2714.4 thousand hectares (Smolstat does not provide information further), whereas in 1990 there were 3,846.2 
thousand hectares, agricultural area was 2212.3 thousand hectares. Milk yield per cow increased from $3167 \mathrm{~kg}$ in 2005 to $4682 \mathrm{~kg}$ in 2018.

In 1980, agricultural production employed more than 120 thousand people, with 437 thousand people living in rural areas. In 2018, the number of people employed in agricultural production, hunting and forestry was 53.9 thousand people, and 278 thousand rural inhabitants in all. Until 1990 Smolensk region occupied the leading place in the production of meat, milk and potatoes. At the same time, over the period from 1971 to 1980 , over 2 billion rubles from the budget were allocated to support the agriculture of the region, which exceeded twice the amount of funds allocated before this period. Currently, subsidies are provided for reimbursement of part of the cost for paying interest on investment loans, on providing unrelated support in crop production, carrying out crops -- technical measures, on developing water supply in rural areas, gasification, arranging housing sites, etc. (from federal budget in total: to purchase elite seeds -- 8 million rubles, for interest reimbursement for a loan -- 9.6 million rubles, cows keeping -- 18.9 million rubles, and other aid). According to Smolstat, in 2005 there were 3022 agricultural, hunting and forestry enterprises, although these are different sectors, but even their number reduced to 1581 units by 2016, and at the beginning of 2018 there were 1537 units.

At the beginning of perestroika period in 1990 there were 5 large meat processing plants in the region. In 1995 there were 15 small enterprises more. At the beginning of 2019 there are 24 companies in Smolensk. 14 companies are located in other cities of the region mainly to import raw materials. There are 89 companies that supply meat in the region. In other branches of agricultural raw materials processing the situation is as follows. In 2004 the total number of dairy companies was 21, alcohol production companies -- 7, vegetable canning companies -- 3. At the beginning of 2019 there were 26 milk processing plants and workshops, and 15 farms and cooperatives independently processed milk. There is only one vegetable canning enterprise, and one feed mill. Alcohol production companies distilleries closed.

In Smolensk region it is possible to divide four natural-economic zones. Small-field contours, weak tillage of agricultural land, and weak development of crop production are typical for the north-west area. Mostly farms are engaged in animal husbandry. The central region reflects a high level of agricultural land development, dairy and beef cattle breeding, potato growing, and greenhouses provide the regional center with necessary foodstuffs [5]. 
The east of the region specializes in dairy and beef cattle breeding, feed production and partly flax farming. The southern territories are well plowed as they have the best natural conditions. The territories process agricultural products, both plant and animal.

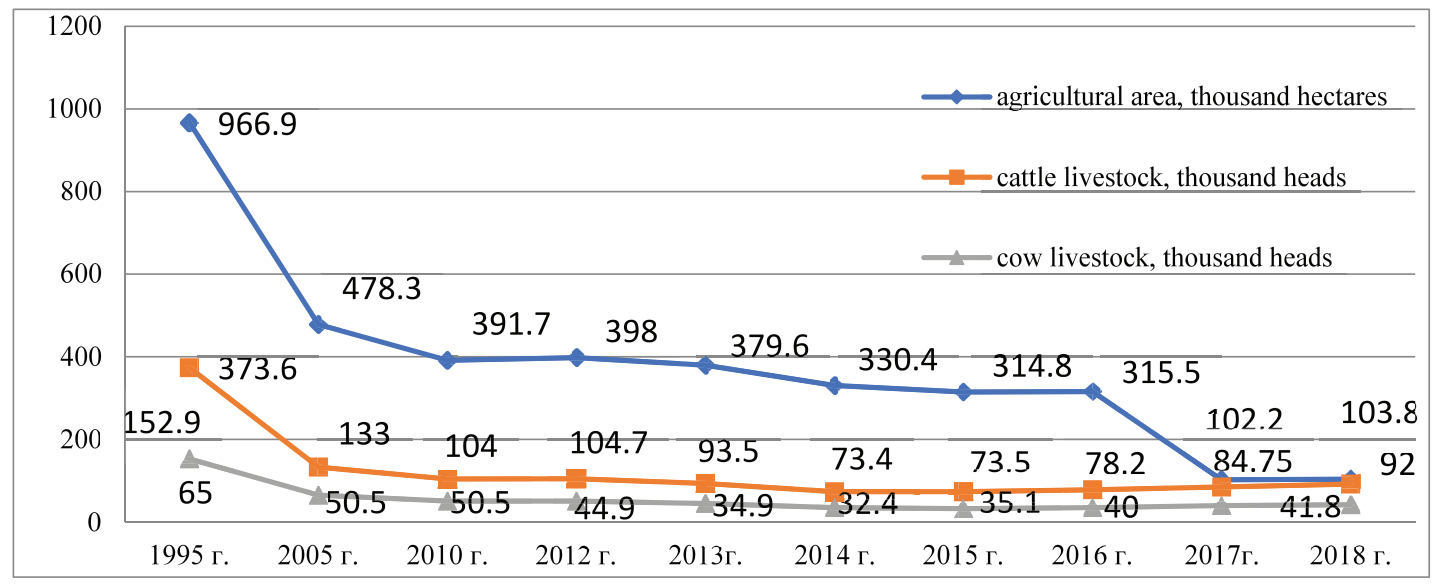

Figure 1: Main indicators dynamics of agricultural production in the region.

At the same time, agricultural enterprises account for more than $40 \%$ of gross output, private farms account for more than $50 \%$, and peasant (farmer) farms produce about $5 \%$. This confirms the thesis that it is impossible to produce agricultural products alone in the conditions of Non-Black Earth Region. Even in the Soviet period, the larger the economy the more profitable it was. Unprofitable farms developed through the redistribution of profits at their expense in the region. Now there is no help. Therefore, it leads to the ruin of the one-man. At the same time, there is a gradual consolidation of farms, through unification, which leads to an improvement in performance: cattle and poultry in live weight of everything in 2005 -- 47.5 thousand tons, in 2018 -- 74.4 thousand tons, grain -- 7.3 thousand tons, in 2018 -- 295 thousand tons, but potatoes, respectively, 230.6 thousand tons, and in 2018 -- 128.5 thousand tons and milk -- 243.6 thousand tons, in 2018 -- 113.8 thousand tons (in 2017 -- 120.2). Thus, there is a specialization in the production of meat and grain. The region is supplied with dairy products by the Republic of Belarus [3].

At the same time, regional and federal authorities follow the established liberal path that does not provide industry development. They support small agricultural businesses and improve the quality of rural settlements. Within this framework, federal and regional programs for agriculture development and regulation of agricultural products markets for 2014--2020 were adopted. The region was included in the activities of the subprogramme for sustainable rural development for 2019. This situation shows the inability of the authorities to take responsibility to restore the sphere of agricultural sector and 
the real development of the regional economy. Assistance to agricultural producers is in the form of subsidies and grants, but their value is negligible, helping in a critical situation, not allowing the development and expansion of the material base. Financial institutions provide borrowed funds for such a risky business on unfavorable terms, where the percentage for a loan exceeds the return on assets of agricultural producers [4].

Thus, there is a situation that shows the artificial nature of restricting industry development, which, in the face of increasing external threats, does not contribute to ensuring the food security of the region and implementation of May presidential decrees.

\section{Purpose of the Study}

The purpose of the study is the development of measures for agricultural sector of the region by creating a reliable mechanism for interaction of all levels: regional authorities, business and society in creating large regional agricultural holdings to solve the following tasks: creating new jobs, improving food security and well-being of citizens, income parts of the regional budget.

\section{Research Methods}

We used monographic, analytical, and trend methods, methods of factor analysis, expert estimates, economic and statistical method and forecasting methods.

\section{Findings}

Measures to increase agricultural production and create farms have led to the impossibility to perform modern material and technical base in the field of agriculture. The experience of the same reforms by Alexander II has already shown that this is a dead end. Numerous studies have shown that only large companies can successfully develop in the Non-Black Earth zone.

Hence, consolidation process should not be accidental, but focused, by influencing it by regional authorities with financing on a priority basis, that is, the creation of regional agricultural sectors. At the same time, it is necessary to restore the infrastructure, since large structures require a reliable service system (seed, fodder, breeding and veterinary facilities, storage and processing, machinery and equipment specialized for the NonBlack Earth zone) that are not dependent on importers under the conditions of sanctions 
and the growth of external threats. Thus, regional authorities will be able to carry out the instructions of the President to create jobs and increase revenues to the regional budget. The studies were presented at scientific conferences and round tables.

\section{Conclusion}

After assessing the forecast state of agricultural sector after the implementation of the proposed measures based on economic and mathematical forecasting and the method of scenarios, the following conclusions were made. According to the pessimistic scenario, the implementation of the proposed measures would increase the gross output of agricultural sector by $19.3 \%$. According to the most probable scenario -by $22.4 \%$, according to the optimistic scenario -- $28.5 \%$. Thus, a new concept for the development of agricultural sector in the region is the concentration of capital in agricultural sector through the targeted consolidation of agricultural companies and creation of large regional agricultural holdings in each municipality of the region through public-private partnership and restoration of rural infrastructure will ensure the solution of socio-economic problems territory. It will lead to food security, new jobs, ability to regulate and control increase the revenue side of the budget, neutralize the negative impact of financial institutions in financing risky business in the conditions of the Black Earth zone, create new jobs, increase well-being of the population of rural settlements and create a trend of the sustainable growth of the socio-economic development of the region.

\section{References}

[1] Aleksanian, S.A., Tsys, V.I. (2018). Development peculiarities of farm dairy cattle breeding. In the collection: Management of sustainable development of rural areas in the region. Materials of the international scientific conference. pp. 162--165.

[2] Belchenko, S.A., Belous, I.N., Naumova, M.P. (2015). Development of agricultural sector in Bryansk region. Bulletin of Bryansk State Agricultural Academy, no. 2--1, pp. 32--36.

[3] Belokopitov, A.V., Dmitrieva, O.E. (2018). Organizational and economic management mechanism of production potential in agricultural sector of economics. In the collection: Management of sustainable development of rural areas in the region. Materials of the international scientific conference, pp. 277--280. 
[4] Chirkov, E.P., Nesterenko, L.N., Khramchenko, A.O., Babiak, M.A. (2018). Problems and possibilities in agricultural development in Bryansk region. Economics of agricultural and processing enterprises, no. 2, pp. 32--37.

[5] Diachenko, O.V. (2005). Organizational and economic development mechanism of integral connection between machine tractor stations with local goods producers. PhD dissertation. Bryansk, Bryansk State Agricultural Academy, 214 p.

[6] Ulianov, N.D. (2013). Information support for agricultural sectors. Innovative approaches to the economic growth concept of the region: materials of the scientific conference. Bryansk. pp. 184--189.

[7] Vorobeva, E.S., Vorobev, O.V. (2018). Priority areas in the development of cattle breeding and strategies for import substitution in the Non-Black zone of Russia. Actual issues on the development of organic farming. Material collection of international scientific conference, p. 355--361. 